\title{
Relationship between carbon dioxide production and performance in cattle and pigs
}

\author{
WERNER JENTSCH, BERNHARD PIATKOWSKI and MICHAEL DERNO
}

\section{Abstract}

An extensive number of metabolic experiments have been carried out at the former Oskar-Kellner-Institute, now the `Oskar Kellner Research Unit of Nutritional Physiology at the Research Institute for the Biology of Farm Animals (FBN), Dummerstorf, on cattle, pigs and humans. Their expired amounts of $\mathrm{CO}_{2}$ having been compiled and stratified with regard to various performance and nutrition levels. The annual $\mathrm{CO}_{2}$ emission of a $700 \mathrm{~kg}$ cow with an annual milk yield of $10000 \mathrm{~kg}$ has been estimated to be $4.7 \mathrm{t}$. With increasing food intake and performance, a concomitant increase of $\mathrm{CO}_{2}$ production per time unit has been observed. However, with increasing performance, we have determined a strong decrease of $\mathrm{CO}_{2}$ output per mass unit of animal-derived food (i.e. meat and milk). This decrease amounts to $40 \%$ when comparing cows with $4000 \mathrm{~kg}$ and $8000 \mathrm{~kg}$ annual milk yields. The $\mathrm{CO}_{2}$ emission per $\mathrm{kg}$ dry matter (DM) intake amounts to $0.55 \mathrm{~kg}$ and is relatively constant, irrespective of live weight and performance. According to this, the world cattle livestock of 1.3 thousand million (UK)/billion (US) individuals produce $6 \%$ of the total yearly $\mathrm{CO}_{2}$ emission of 30 thousand million (UK)/billion (US) t. Similarly, in pigs, increasing daily weight gains of an additional $200 \mathrm{~g}$ result in a reduction of $10-15 \%$ of $\mathrm{CO}_{2}$ emissions. Sows produce $1.5-1.7 \mathrm{~kg} \mathrm{CO}$ daily; fattening pigs and humans each produce $1 \mathrm{~kg} \mathrm{CO}$.

Keywords: $\mathrm{CO}_{2}$ production, dairy cattle, bulls, swine, food intake, performance level, human

\section{Zusammenfassung}

\section{Zusammenhang zwischen Kohlendioxidproduktion und Leistung bei Rind und Schwein}

Aus dem umfangreichen Fundus der im Oskar-Kellner-Institut, seit 1992 ein Forschungsbereich des FBN Dummerstorf, durchgeführten Gesamtstoffwechselversuche wurden die mit den Atemgasen von Rind, Schwein und Mensch bei verschiedenen Leistungen und unterschiedlicher Ernährung abgegebenen $\mathrm{CO}_{2}$-Mengen zusammengestellt. Dabei wurde ein Anstieg der $\mathrm{CO}_{2}$-Produktion mit ansteigender Nahrungsaufnahme und zunehmender Leistung in der Zeiteinheit aufgezeigt. Es konnte aber auch ein starker Rückgang in der $\mathrm{CO}_{2}$-Abgabe je Masseeinheit erzeugtes Produkt mit ansteigender Leistung nachgewiesen werden. Dieser Rückgang betrug beim Vergleich der Jahresleistungen von 4000 und $8000 \mathrm{~kg}$ Milch $40 \%$. Unabhängig von der Lebendmasse und Leistung der Kühe blieb die $\mathrm{CO}_{2}-$ Emission je $\mathrm{kg}$ verzehrter Trockensubstanz bei $0,55 \mathrm{~kg}$ relativ konstant. Danach sind die weltweit lebenden 1,3 Milliarden Rinder mit $6 \%$ an der jährlich freigesetzten $\mathrm{CO}_{2}$-Menge von ca. 30 Milliarden t beteiligt. Auch bei Schweinen bestätigt sich der Trend, dass bei 
$200 \mathrm{~g}$ höheren Tageszunahmen die $\mathrm{CO}_{2}$-Abgabe um 10-15\% sinkt. Zuchtsauen gaben täglich 1,5-1,7 kg CO 2 und Mastschweine ebenso wie der Mensch 1 kg CO 2 ab.

Schlüsselwörter: $\quad \mathrm{CO}_{2}$-Produktion, Milchvieh, Aufzuchtrinder, Mastbullen, Sauen, Mastschweine, Futteraufnahme, Leistungsniveau, Mensch

\section{Introduction}

In the global discussion about climate change, the reduction of the current carbon dioxide $\left(\mathrm{CO}_{2}\right)$ released into the atmosphere stands in the spotlight of public interest. Increasing $\mathrm{CO}_{2}$ concentrations are the largest source of global warming. According to the annual review of the World Meteorological Organization in Geneva, $\mathrm{CO}_{2}$ contributes to $63 \%$ of the greenhouse effect, based on an annual increase in emissions of about 25 to 28 thousand million (UK)/billion (US) t from 2000 to 2005. The main cause is the massive and partly wasteful use of energy sources such as coal, petroleum and natural gas by the human population during the past 50 years (IPCC Report 2007).

$\mathrm{CO}_{2}$ represents one of the trace gases in the atmosphere with a share of $0.03 \%$, in contrast to $77.1 \%$ nitrogen and $20.8 \%$ oxygen. In addition, air contains $1.1 \%$ hydrogen, $0.9 \%$ argon and $0.1 \%$ trace gases, including $0.03 \%$ of $\mathrm{CO}_{2}$. An increase of $\mathrm{CO}_{2}$ to $0.04 \%$ is assumed.

Notwithstanding this small proportion, $\mathrm{CO}_{2}$ is of fundamental importance to life on earth, because glucose, starch, cellulose and other organic sources of energy and materials arise from $\mathrm{CO}_{2}$ and water through photosynthesis via the exposure of chlorophyll to light energy. Therefore, in this context, $\mathrm{CO}_{2}$ can be considered as a plant nutrient.

Together with the current classification of the involvement of $\mathrm{CO}_{2}$ in global warming, the role of sunspot activity, natural cloud cover and water vapour are being evaluated and classified as other influential factors (IPCC Report 2007).The aim of this work has been to estimate the $\mathrm{CO}_{2}$ production of our two most important livestock animals, viz. cattle and pigs, and also from humans on the basis of experimental data similar to those obtained for heat (JENTSCH et al. 2001) and methane (JENTSCH et al. 2007) production.

\section{Material and methods}

Because of the technical effort involved, precise measurements of $\mathrm{CO}_{2}$ production have been carried out worldwide in only a few institutes and are unlikely to be carried out in the future with the same complexity and form as described in this report. One of these institutes, the Oskar Kellner Institute (OKI), which was founded by K. Nehring in 1953 and further supported by the Rostock group of scientists including R. Schiemann, L. Hoffmann and W. Jentsch, has belonged since 1970 as a research unit to the Research Centre at Dummerstorf and, from 1992, has been known as the Research Unit of Nutritional Physiology >Oskar Kellner at the FBN Dummerstorf.

The investigation of this problem has taken into account those factors that influence metabolism and thus $\mathrm{CO}_{2}$ production, such as the nutrient composition of the diet and nutritional and performance levels. These are the same factors that determine energy requirements and have been used for the calculation of energy requirements. 
The values of $\mathrm{CO}_{2}$ production are means from 4-5-day periods. The data for dairy cows are based on 198 total metabolic periods the results of which have been published in several reports, but without a direct description of the $\mathrm{CO}_{2}$ production values. Results for maintenance energy requirements and energy utilization for milk production (SCHIEMANN et al. 1970), for energy utilization at various performance levels or during lactation (HOFFMANN et al. 1972), for utilization of body energy for milk production from measurements during 26 periods (SCHIEMANN et al. 1974) and for other aspects have been used for the derivation of energy standards for cows (HOFFMANN et al. 1974). These results essentially agree with those in the literature (FLATT et al. 1969, VAN ES and NIJKAMP 1969).

Using heifers (rearing cattle), we carried out (SCHIEMANN et al. 1987) 6 series of experiments involving different rates of growth of the young cattle and at different ages at their first calving; these results formed the basis for the formulation of energy standards (HOFFMANN et al. 1988, HOFFMANN and JENTSCH 1988).

With young bulls, 14 trials were carried out at high production levels (SCHIEMANN et al. 1976) and further experiments with lower body weight gains (JENTSCH et al. 1977, 1978, WITTENBURG et al. 1976). On the basis of these experiments and the results of the performance testing of bulls of various breeds (BLISCHKE 1978), improved energy standards were obtained (HOFFMANN et al. 1981) and published as the revised Rostock feed evaluation system (JENTSCH et al. 2004).

In order to improve the energy standards of pregnant and lactating sows, nine trials were carried out with sows in various reproductive cycles and receiving various energy supplies (BEYER et al. 1994, 1995). These results formed the basis for the derivation of the requirement standards for sows (HOFFMANN et al. 1990).

Experiments with Landrace pigs (JENTSCH and HOFFMANN 1977) and with hybrid pigs (JENTSCH et al. 1983) raised under various feeding regimes were used to calculate the requirement standards (HOFFMANN et al. 1979, 1983, JENTSCH et al. 2004).

For all measurements of energy turnover and calculations, the following units were used (HOFFMANN and SCHIEMANN 1980) - $\mathrm{CO}_{2}: 1.964 \mathrm{~g} / \mathrm{l}, 1 \mathrm{l}=0.509 \mathrm{~g} ; \mathrm{CH}_{4}: 0.716 \mathrm{~g} / \mathrm{l}$, $39.57 \mathrm{~kJ} / \mathrm{l} ; \mathrm{O}_{2}: 1.428 \mathrm{~g} / \mathrm{l} ; \mathrm{C}$-content: protein $52.00 \%$, fat $76.70 \%$, carbohydrates $44.45 \%$. Calculation of heat production (HP) for volumetric measurement of gas exchange (BROUWER 1965):

$$
\mathrm{HP}=16.19 \cdot \mathrm{O}_{2}+5.02 \cdot \mathrm{CO}_{2}-2.17 \cdot \mathrm{CH}_{4}-5.99 \cdot \text { urinary } \mathrm{N} \text { - }
$$

The comprehensive presentation of the $\mathrm{CO}_{2}$ formation of animals at different production levels was similar to the approach in the report on HP of dairy cows (JENTSCH et al. 2001). The calculations were not based on individual measurements, but generalized derivations for energy requirements were used. Thus, the $\mathrm{CO}_{2}$ emissions were estimated by taking into account the partial coefficients of utilization for different production levels.

The data were recalculated from energy standards derived from results that were evaluated by a commission under the supervision of L. Hoffmann. The energy standards were derived after statistical processing of the experimental data.

The energy requirements are given as a net energy retention, according to the main animal species and different performance levels (JENTSCH et al. 2004). Based on these values, the recalculation will be demonstrated in two examples. 
Example 1: $\mathrm{CO}_{2}$ production during lactation

$1 \mathrm{~kg}$ ECM (energy corrected milk, milk with 4\% fat), energy requirement $=2.99 \mathrm{MJ}$ net energy retention (NER), with a utilization of metabolizible energy (ME) for milk production of $62 \%$, ME results to $4.82 \mathrm{MJ}$, difference $=1.83 \mathrm{MJ}$ HP per $\mathrm{kg} \mathrm{ECM}$.

Because, in agricultural animal husbandry, the feeding level is higher, a respiratory quotient (RQ) of 1.0 to 1.3 can be assumed. According to the equation for calculating $\mathrm{HP}$, we then obtain, for $1000 \mathrm{~kJ} \mathrm{HP}, 93-112 \mathrm{~g} \mathrm{CO}_{2}$. Per kg milk, $1.83 \cdot 106=194 \mathrm{~g} \mathrm{CO}_{2}$ will be exhaled when a $R Q=1.2$ is assumed. At maintenance feeding, a $R Q$ of 0.85 is assumed.

Although not important for this problem, we should mention that $10-12 \%$ of the total $\mathrm{CO}_{2}$ exhaled arises from $\mathrm{CO}_{2}$ produced by rumen fermentation.

Example 2: $\mathrm{CO}_{2}$ production in the pig

Fattening pig, $100 \mathrm{~kg}$ BW (body weight), $700 \mathrm{~g} \mathrm{BW}$ gain, energy requirement $=27.2 \mathrm{MJ}$ NER, with a utilization of ME for growth of $70 \%$, ME results to $38.9 \mathrm{MJ}$, difference $=11.7 \mathrm{MJ}$ of $\mathrm{HP}$ per animal and day at a $\mathrm{RQ}$ of $1.30,11.7 \cdot 112 \mathrm{~g} \mathrm{CO}_{2}=1310 \mathrm{~g} \mathrm{CO}_{2}$ per animal and day.

The $\mathrm{CO}_{2}$ emissions from various animal categories and production levels were calculated according to the examples given above. The lower emissions at high production levels in early lactation resulting from the utilization of body energy for milk production were not taken into account because body mass has to be recovered after the end of lactation

\section{Results and discussion}

\section{$\mathrm{CO}_{2}$ production by adult cattle on maintenance feeding}

The values in Table 1 should be seen as starting values if, for example, $\mathrm{CO}_{2}$ emissions for milk production are to be calculated as the sum of maintenance feeding and feeding for milk production. At the maintenance level, the ME (e.g. 28 MJ NER in bovines [NERb] corresponds at $55 \%$ utilization to $51 \mathrm{MJ} M E)$ equals $\mathrm{HP}$ and yields $(\mathrm{RQ}=0.85) 4.18 \mathrm{~kg}$ of $\mathrm{CO}_{2}$. The increase in $\mathrm{CO}_{2}$ production parallels the higher feed intake of heavier animals, whereby per $1 \mathrm{~kg} / \mathrm{DM}$ intake, the $\mathrm{CO}_{2}$ production is equal to $0.63 \mathrm{~kg}$. The DM intake values of cows were based on information provided by PIATKOWSKI et al. (1990), which were also used in the following.

Table 1

Daily $\mathrm{CO}_{2}$ production of adult cattle of various body weights at maintenance feeding level Tägliche $\mathrm{CO}_{2}$-Produktion adulter Rinder mit unterschiedlicher Lebendmasse unter Erhaltungsfütterung

\begin{tabular}{lccc}
\hline Body weight, $\mathrm{kg}$ & $\begin{array}{c}\text { Maintenance energy } \\
\text { requirement, MJ NERb/d }\end{array}$ & $\mathrm{CO}_{2}, \mathrm{~kg} / \mathrm{d}$ & $\mathrm{CO}_{2}, \mathrm{~kg} / \mathrm{kg}$ DM intake \\
\hline 500 & 28 & 4.18 & 0.63 \\
600 & 33 & 4.92 & 0.63 \\
700 & 37 & 5.52 & 0.63 \\
800 & 41 & 6.12 & 0.63 \\
\hline
\end{tabular}

$\mathrm{NERb}$ net energy retention in bovines 


\section{$\mathrm{CO}_{2}$ production during milk production}

During the production of $1 \mathrm{~kg}$ of milk, $194 \mathrm{~g}_{\text {of }} \mathrm{CO}_{2}$ will be formed, as shown in Example 1. From this, multiples for $\mathrm{CO}_{2}$ production are listed in Table 2.

Table 2

Daily $\mathrm{CO}_{2}$ production during milk production at various performance levels without consideration of maintenance requirement

Tägliche $\mathrm{CO}_{2}$-Produktion bei der Milchbildung bei unterschiedlichem Leistungsniveau ohne Berücksichtigung des Erhaltungsbedarfs

\begin{tabular}{lcc}
\hline Milk (ECM), kg/d & Energy requirement, MJ NERb & $\mathrm{CO}_{2}, \mathrm{~kg} / \mathrm{d}$ \\
\hline 10 & 30 & 1.95 \\
20 & 60 & 3.90 \\
30 & 90 & 5.85 \\
40 & 120 & 7.80 \\
50 & 150 & 9.75 \\
\hline
\end{tabular}

$\mathrm{NERb}$ net energy retention in bovines

With these values and those from in Table 1, column 3, the $\mathrm{CO}_{2}$ emission from maintenance and milk production can be calculated (Table 3 )

Table 3

Daily $\mathrm{CO}_{2}$ production of cows as affected by body weight and milk yield, and $\mathrm{CO}_{2}$ production per $\mathrm{kg}$ feed $\mathrm{DM}$ Tägliche $\mathrm{CO}_{2}$-Produktion von Kühen in Abhängigkeit von Lebendmasse und Tagesmilchleistung und $\mathrm{CO}_{2}-$ Produktion je kg Futter-Trockensubstanz

\begin{tabular}{lcccccccc}
\hline Milk (ECM), kg/d & \multicolumn{3}{c}{$\mathrm{kg} \mathrm{CO} / \mathrm{d}$ from milk + maintenance } & \multicolumn{5}{c}{$\mathrm{kg} \mathrm{CO}_{2}$ per kg feed DM } \\
& $500 \mathrm{~kg} \mathrm{BW}$ & $600 \mathrm{~kg} \mathrm{BW}$ & $700 \mathrm{~kg} \mathrm{BW}$ & $800 \mathrm{~kg} \mathrm{BW}$ & $500 \mathrm{~kg} \mathrm{BW}$ & $600 \mathrm{~kg}$ BW & $700 \mathrm{~kg} \mathrm{BW} 800 \mathrm{~kg}$ BW \\
\hline 10 & 6.13 & 6.87 & 7.47 & 8.07 & 0.53 & 0.55 & 0.55 & 0.55 \\
20 & 8.08 & 8.82 & 9.42 & 10.02 & 0.54 & 0.55 & 0.55 & 0.56 \\
30 & 10.03 & 10.77 & 11.37 & 11.97 & 0.55 & 0.56 & 0.56 & 0.56 \\
40 & - & 12.72 & 13.32 & 13.92 & - & 0.56 & 0.56 & 0.56 \\
50 & - & - & 15.27 & 15.87 & - & - & $(0.56)$ & $(0.56)$ \\
\hline
\end{tabular}

The $\mathrm{CO}_{2}$ production per day increases with milk yield (Table 3 ) but, per kg DM intake, only small changes in a narrow range of $0.53-0.56 \mathrm{~kg}$ occur. The two values of 0.56 in the last line of Table 3 are given in parentheses because, at this stage, the milk is formed partly from body energy.

Table 4

$\mathrm{CO}_{2}$ production per kg milk at various performance and body weight levels

Die $\mathrm{CO}_{2}$-Abgabe je kg produzierte Milch bei unterschiedlicher Milchleistung und Lebendmasse

\begin{tabular}{lcc}
\hline Milk (ECM), kg/d & $\mathrm{CO}_{2}$ emission per kg of produced milk, kg \\
$600 \mathrm{~kg} \mathrm{BW}$ & $800 \mathrm{~kg} \mathrm{BW}$ \\
\hline 10 & 0.7 & 0.8 \\
20 & 0.44 & 0.5 \\
30 & 0.36 & 0.4 \\
40 & 0.32 & 0.35 \\
50 & - & 0.32 \\
\hline
\end{tabular}


The $\mathrm{CO}_{2}$ emission per $\mathrm{kg}$ of milk significantly decreases with increasing milk yield (Table 4). For $40 \mathrm{~kg}$ of milk per day, the $\mathrm{CO}_{2}$ output per $\mathrm{kg}$ of milk amounts only to $40-45 \%$ of the level at $10 \mathrm{~kg}$ milk.

In the discussion on results of the various, sometimes contradictory, experimental results regarding the development of $\mathrm{CO}_{2}$ "footprints «, a decrease in $\mathrm{CO}_{2}$ output per $\mathrm{kg}$ of milk with increasing milk yield has been suggested (FLACHOWSKY 2008). This decrease is now established by the data in Table 4.

The distinction between conventional and ecological production is irrelevant, if only the emissions from the animals are considered. Here, the presented performance-related dependencies are valid. The higher emissions during ecological production because of lower yields are partially compensated by the reduced use of technology or the use of lower quantities of complementary or supplementary feed. In the present publication, only the animal-related $\mathrm{CO}_{2}$ emissions are analysed.

The $\mathrm{CO}_{2}$ production in the dry period is shown in Table 5 .

Table 5

$\mathrm{CO}_{2}$ production of cows at $600 \mathrm{~kg}$ body weight during the dry period

Die $\mathrm{CO}_{2}$-Produktion in der Trockenstehzeit bei Kühen mit $600 \mathrm{~kg}$ Lebendmasse

\begin{tabular}{lcccccc}
\hline $\begin{array}{l}\text { Days before } \\
\text { calving }\end{array}$ & \multirow{2}{*}{ ER, MJ NERb } & \multicolumn{3}{c}{$\mathrm{CO}_{2}, \mathrm{~kg} / \mathrm{d}$} & \multicolumn{3}{c}{$\mathrm{CO}_{2}, \mathrm{~kg}$} \\
\hline $60-41$ & 46 & 4.9 & 7.1 & 12.0 & 240 & \\
$40-21$ & 56 & 4.9 & 12.5 & 17.4 & 350 & \\
$20-1$ & 58 & 4.9 & 13.6 & 18.5 & 370 & 960 \\
\hline
\end{tabular}

ER energy requirement, $\mathrm{NERb}$ net energy retention in bovines

The partition into "maintenance « and "conception« is useful as it takes into account the low utilization of ME for the formation of conception products by $15-20 \%$ attributable to the increasing maintenance requirement in this period.

Table 6

Annual $\mathrm{CO}_{2}$ production as affected by milk performance and body weight, dry period included

Jährliche $\mathrm{CO}_{2}$-Produktion in Abhängigkeit von der Milchleistung und Lebendmasse, einschließlich Trockenperiode

\begin{tabular}{lccccc}
\hline \multirow{2}{*}{$\begin{array}{l}\text { Annual performance, } \\
\mathrm{kg} \mathrm{milk} / \mathrm{a}(\mathrm{ECM})\end{array}$} & $500 \mathrm{~kg} \mathrm{BW}$ & $600 \mathrm{~kg} \mathrm{BW}$ & $700 \mathrm{~kg} \mathrm{BW}$ & $800 \mathrm{~kg} \mathrm{BW}$ & $\mathrm{CO}_{2}, \mathrm{~kg} / \mathrm{kg} \mathrm{milk*}$ \\
\hline 4000 & $2985(100)$ & $3255(100)$ & $3475(100)$ & $3695(100)$ & 0.87 \\
6000 & $3345(112)$ & $3615(111)$ & $3835(110)$ & $4055(110)$ & 0.64 \\
8000 & $3765(126)$ & $4035(124)$ & $4255(122)$ & $4480(121)$ & 0.53 \\
10000 & - & $4460(137)$ & $4675(135)$ & $4895(132)$ & 0.47 \\
12000 & - & - & $5040(145)$ & $5260(142)$ & 0.42 \\
\hline
\end{tabular}

* calculated for cows with $700 \mathrm{~kg} \mathrm{BW,} \mathrm{Values} \mathrm{in} \mathrm{parenthesis} \mathrm{are} \mathrm{related} \mathrm{to} \mathrm{values} \mathrm{in} \mathrm{the} \mathrm{top} \mathrm{row.}$

The values in Table 6 for the $\mathrm{CO}_{2}$ production of the cows are the sum of $\mathrm{CO}_{2}$ emissions in the lactation and dry periods. The body-weight-related differences in the dry period also are taken into account. As an example, the $\mathrm{CO}_{2}$ production of a $700-\mathrm{kg}$ cow with a milk yield of 4000 or $8000 \mathrm{~kg}$ increases from 3.48 to 4.26 tons, i.e. by $20 \%$. In contrast, the $\mathrm{CO}_{2}$ production per $\mathrm{kg}$ of milk decreases significantly from 0.87 to $0.53 \mathrm{~kg}$ per $\mathrm{kg}$ milk, i.e. by $40 \%$. 


\section{$\mathrm{CO}_{2}$ production of young female cattle and fattening bulls}

For heifers and fattening bulls, the $\mathrm{CO}_{2}$ production increases with increasing body weight of the animals and the gain in body weight but decreases with increasing daily gain in body weight (Table 7).

\section{Table 7}

$\mathrm{CO}_{2}$ production of heifers and young fattening bulls in $\mathrm{kg}$ per day, $\mathrm{kg}$ per $\mathrm{kg}$ body weight gain, and $\mathrm{kg}$ per kg dry matter intake depending on body weight and daily gain

Die $\mathrm{CO}_{2}$-Produktion weiblicher Jungrinder und von Mastbullen in Abhängigkeit von Lebendmasse und Lebendmassezunahme (LMZ) je Tier und Tag, je kg LMZ und je kg Trockensubstanzaufnahme

\begin{tabular}{|c|c|c|c|c|c|}
\hline \multirow{2}{*}{ BW, kg } & \multirow{2}{*}{ BWG, g } & \multirow{2}{*}{ ER, MJ NERb } & \multicolumn{3}{|c|}{$\mathrm{CO}_{2}$ production } \\
\hline & & & $\mathrm{kg} / \mathrm{d}$ & $\mathrm{kg} / \mathrm{kg} \mathrm{BWG}$ & $\mathrm{kg} / \mathrm{kg}$ DMI \\
\hline \multicolumn{6}{|l|}{ Heifers } \\
\hline \multirow[t]{3}{*}{200} & 400 & 21.0 & 1.65 & 4.12 & 0.38 \\
\hline & 600 & 25.7 & 2.10 & 3.50 & 0.42 \\
\hline & 800 & 31.0 & 2.61 & 3.26 & 0.48 \\
\hline \multirow[t]{3}{*}{300} & 400 & 29.4 & 2.31 & 5.78 & 0.37 \\
\hline & 600 & 35.7 & 2.92 & 4.87 & 0.44 \\
\hline & 800 & 44.6 & 3.76 & 4.70 & 0.54 \\
\hline \multirow[t]{3}{*}{400} & 400 & 37.8 & 2.97 & 7.43 & 0.50 \\
\hline & 600 & 43.6 & 3.57 & 5.95 & 0.42 \\
\hline & 800 & 49.4 & 4.16 & 5.20 & 0.50 \\
\hline \multirow[t]{3}{*}{500} & 400 & 42.0 & 3.30 & 8.25 & 0.42 \\
\hline & 600 & 48.3 & 3.95 & 6.58 & 0.47 \\
\hline & 800 & 54.1 & 4.56 & 5.70 & 0.50 \\
\hline \multicolumn{6}{|c|}{ Fattening bulls } \\
\hline \multirow[t]{3}{*}{200} & 800 & 24.7 & 2.08 & 2.60 & 0.47 \\
\hline & 1000 & 26.8 & 2.32 & 2.32 & 0.50 \\
\hline & 1200 & 28.9 & 2.58 & 2.15 & 0.54 \\
\hline \multirow[t]{3}{*}{300} & 1000 & 38.3 & 3.32 & 3.32 & 0.46 \\
\hline & 1200 & 42.0 & 3.75 & 3.12 & 0.51 \\
\hline & 1400 & 46.2 & 4.23 & 3.02 & 0.54 \\
\hline \multirow[t]{3}{*}{400} & 1000 & 47.8 & 4.15 & 4.15 & 0.45 \\
\hline & 1200 & 52.5 & 4.68 & 3.90 & 0.50 \\
\hline & 1400 & 57.8 & 5.30 & 3.79 & 0.55 \\
\hline \multirow[t]{3}{*}{500} & 1000 & 56.7 & 4.92 & 4.92 & 0.49 \\
\hline & 1200 & 62.5 & 5.57 & 4.64 & 0.54 \\
\hline & 1400 & 68.8 & 6.30 & 4.50 & 0.58 \\
\hline
\end{tabular}

BWG body weight gain, ER energy requirement, NERb net energy retention in bovines, DMI dry matter intake

As shown in the last columns of both sections, the $\mathrm{CO}_{2}$ output per $\mathrm{kg} \mathrm{DM}$ intake in the heifers is in the range of $0.37-0.54 \mathrm{~kg}$ and in the fattening bulls of $0.45-0.58 \mathrm{~kg}$, increasing with increasing daily body weight gain. For non-lactating cows, we calculated a value of $0.6 \mathrm{~kg}$, and for lactating cows of $0.5-0.6 \mathrm{~kg}$. The difference between the heifers and fattening bulls is attributable to the different performance levels. Higher daily gains of $800 \mathrm{~g}$ compared with $400 \mathrm{~g}$ in heifers and from $1400 \mathrm{~g}$ compared with $1000 \mathrm{~g}$ in fattening bulls lead to $20-30 \%$ and $10 \%$ lower $\mathrm{CO}_{2}$ emissions, respectively. 


\section{$\mathrm{CO}_{2}$ production of breeding sows}

Pregnant and lactating sows emit 1.0-1.4 or $1.2-1.8 \mathrm{~kg} \mathrm{CO}_{2}$ per day with regard to sows differentiated by age and course of lactation (Tables 8 and 9 ).

Table 8

$\mathrm{CO}_{2}$ production of pregnant sows

Die $\mathrm{CO}_{2}$-Produktion trächtiger Sauen

\begin{tabular}{lccccccccc}
\hline $\begin{array}{l}\text { Number of } \\
\text { pregnancy }\end{array}$ & \multicolumn{9}{c}{$\begin{array}{c}\text { Day of pregnancy } \\
85-84\end{array}$} \\
& $\mathrm{BW}, \mathrm{kg}$ & $\mathrm{NERs}, \mathrm{MJ}$ & $\mathrm{CO}_{2}, \mathrm{~kg} / \mathrm{d}$ & $\mathrm{BW}, \mathrm{kg}$ & $\mathrm{NERs}, \mathrm{MJ}$ & $\mathrm{CO}_{2}, \mathrm{~kg} / \mathrm{d}$ & $\mathrm{BW}, \mathrm{kg}$ & NERs, $\mathrm{MJ}^{\mathrm{CO}_{2}, \mathrm{~kg} / \mathrm{d}}$ \\
\hline 1 & 150 & 22.1 & 1.00 & 180 & 25.0 & 1.12 & 190 & 28.7 & 1.28 \\
2 & 180 & 24.3 & 1.09 & 210 & 25.7 & 1.15 & 220 & 29.4 & 1.31 \\
3 & 200 & 25.0 & 1.12 & 225 & 26.5 & 1.18 & 235 & 30.1 & 1.35 \\
$4-8$ & 220 & 25.0 & 1.12 & 240 & 27.2 & 1.22 & 250 & 31.5 & 1.40 \\
\hline
\end{tabular}

NERs net energy retention in swine

Per kg DM intake (these data are not included in the tables), the $\mathrm{CO}_{2}$ emission of pregnant sows amounts to $0.35 \mathrm{~kg}$ at the beginning of pregnancy and to $0.43 \mathrm{~kg}$ at the end. This is correlated with the decreased utilization of feed and/or the increasing maintenance energy requirement at the end of pregnancy. The lactating sows emit uniformly $0.34 \mathrm{~kg}$ of $\mathrm{CO}_{2}$ per $\mathrm{kg}$ DM intake.

Table 9

$\mathrm{CO}_{2}$ production of lactating sows

Die $\mathrm{CO}_{2}$-Produktion laktierender Sauen

\begin{tabular}{|c|c|c|c|c|c|c|c|c|c|}
\hline \multirow{3}{*}{$\begin{array}{l}\text { Number of } \\
\text { lactation }\end{array}$} & \multirow{3}{*}{ BW, kg } & \multicolumn{8}{|c|}{ Week of lactation } \\
\hline & & \multicolumn{2}{|c|}{1} & \multicolumn{2}{|r|}{2} & \multicolumn{2}{|c|}{ 3-6 } & \multicolumn{2}{|r|}{7} \\
\hline & & NERs, MJ & $\mathrm{CO}_{2}, \mathrm{~kg} / \mathrm{d}$ & NERs, MJ & $\mathrm{CO}_{2}, \mathrm{~kg} / \mathrm{d}$ & NERs, MJ & $\mathrm{CO}_{2}, \mathrm{~kg} / \mathrm{d}$ & NERs, MJ & $\mathrm{CO}_{2}, \mathrm{~kg} / \mathrm{d}$ \\
\hline 1 & 175 & 34.5 & 1.20 & 39.0 & 1.35 & 42.6 & 1.50 & 39.0 & 1.35 \\
\hline 2 & 200 & 44.1 & 1.55 & 50.0 & 1.75 & 50.0 & 1.75 & 46.3 & 1.65 \\
\hline 3 & 215 & 45.6 & 1.60 & 51.4 & 1.80 & 51.4 & 1.80 & 47.8 & 1.70 \\
\hline $4-8$ & 230 & 42.6 & 1.50 & 47.8 & 1.70 & 51.4 & 1.80 & 47.0 & 1.65 \\
\hline
\end{tabular}

NERs net energy retention in swine

The $\mathrm{CO}_{2}$ production of lactating sows in the 8th lactation week approximates that in the 1st lactation week.

\section{$\mathrm{CO}_{2}$ production of fattening pigs}

In fattening pigs, the differentiation of body weight and the increase in body weight is reflected in $\mathrm{CO}_{2}$ production. Higher body weight gains lead to lower $\mathrm{CO}_{2}$ emissions per $\mathrm{kg}$ gain and, on the basis of per $\mathrm{kg}$ feed intake, they are equal at about $0.46-0.48 \mathrm{~kg}$. 
Table 10

$\mathrm{CO}_{2}$ production of fattening pigs

Die $\mathrm{CO}_{2}$-Produktion von Mastschweinen

\begin{tabular}{lccccc}
\hline BW, kg & BWG, g & ER, MJ NERs & kg/d & $\begin{array}{c}\mathrm{CO}_{2} \text { production } \\
\mathrm{kg} / \mathrm{kg} \text { BWG }\end{array}$ & $\mathrm{kg} / \mathrm{kg} \mathrm{DMI}$ \\
\hline 40 & 500 & 14.0 & 0.67 & 1.34 & 0.46 \\
& 700 & 18.4 & 0.88 & 1.26 & 0.46 \\
60 & 400 & 15.4 & 0.74 & 1.85 & 0.46 \\
& 600 & 19.8 & 0.95 & 1.58 & 0.46 \\
80 & 800 & 24.3 & 1.17 & 1.46 & 0.47 \\
& 400 & 17.6 & 0.85 & 2.11 & 0.48 \\
100 & 600 & 22.8 & 1.09 & 1.82 & 0.48 \\
& 800 & 27.9 & 1.34 & 1.67 & 0.48 \\
120 & 500 & 22.0 & 1.06 & 2.11 & 0.48 \\
& 700 & 27.2 & 1.31 & 1.87 & 0.48 \\
& 500 & 23.5 & 1.13 & 2.26 & 0.48 \\
\hline
\end{tabular}

BWG body weight gain, ER energy requirement, NERs net energy retention in swine, DMI dry matter intake

\section{$\mathrm{CO}_{2}$ production of humans}

$\mathrm{CO}_{2}$ production was also measured in three trials involving men over 50 years of age (methodological aspects, JUNGHANS et al. 2008; determination of the utilization of starch for fat retention, JENTSCH et al. 2000) in respiration chambers (Table 11). In trial 1, the subjects were fasted overnight for $12 \mathrm{~h}$ and remained in a sitting position for $3 \mathrm{~h}$ in the respiration chamber. The measured values of experiments 2 and 3 were obtained in a difference trial with the person remaining in the respiration chamber three times for $23 \mathrm{~h}$ under similar activity programmes (eating, exercise in the chamber, sitting at a desk) on each experimental day. The basic diet in the experiment 2 covered the energy maintenance requirement with a slightly positive balance and, in experiment 3 , the energy retention from the diet supplement was $5200 \mathrm{~kJ} /$ day.

Table 11

$\mathrm{CO}_{2}$ production of men aged 50 years and more

Die $\mathrm{CO}_{2}$-Produktion von >50-jährigen Männern

\begin{tabular}{lllc}
\hline Trial & Nutritional level & $n$ & $\mathrm{CO}_{2}$ production, $\mathrm{kg} / \mathrm{d}$ \\
\hline 1 & Fasting & 8 & $0.74 \pm 0.047$ \\
2 & Maintenance & 3 & $0.81 \pm 0.055$ \\
3 & Energy retention & 3 & $1.06 \pm 0.058$ \\
\hline
\end{tabular}

During fasting, $\mathrm{CO}_{2}$ production was $10 \%$ lower than under a maintenance diet; however, because of the small sample size, the values fluctuated greatly. In trial $3, \mathrm{CO}_{2}$ production was $30 \%$ higher than that in the 2 nd trial. The $\mathrm{CO}_{2}$ production of a man of approximately $75 \mathrm{~kg}$ in weight can be set to $1 \mathrm{~kg}$ per day, if his activity is in the medium range. With intense exercise or heavy physical work, a $20 \%$ higher output can be expected. 


\section{Conclusions}

The presented results relate to the $\mathrm{CO}_{2}$ emissions resulting from nutrient and energy turnover of the food in the body of cattle and pigs. Those that occur additionally through the use of technology have not been included.

The approach chosen to estimate $\mathrm{CO}_{2}$ production by using energy requirement standards ensure a higher degree of generalization in comparison with individual measurements. This is particularly true as the energy standards have been examined and confirmed under production conditions, (BLISCHKE 1978, FRANKE 1977, GUTBIER 1984). As the obtained energy standards and coefficients of utilization are compared with those in the literature, we can assume similar $\mathrm{CO}_{2}$ emissions. Model calculations and comparisons of feed evaluation and standards for various species (SCHIEMANN et al. 1982, VAN DER HONING and STEG 1980, 1990) show good agreement.

The information obtained on the basis of experimental data in cattle is relevant on two counts: the daily $\mathrm{CO}_{2}$ release of a $700 \mathrm{~kg}$ cow yielding 10 or $30 \mathrm{~kg}$ of milk increases from 7.5 to $11.4 \mathrm{~kg}$ but, at the same time, the $\mathrm{CO}_{2}$ output per $\mathrm{kg}$ of milk drops by $40 \%$. For a desired amount of milk, a higher milk production per animal requires a smaller number of animals, whereby the maintenance energy requirement is lower and, correspondingly, the release of $\mathrm{CO}_{2}$ is reduced.

Thus, the negative image previously associated with the name sturbo-cows is now repudiated and reflects the opposite of what the coiners of the word once thought.

The above results show that the $\mathrm{CO}_{2}$ emission per $\mathrm{kg}$ of DM consumed, regardless of the performance and body weight, is relatively constant at $0.55 \mathrm{~kg}$ per cow. Thus, we can now provide more accurate information on the $\mathrm{CO}_{2}$ release of the world's 1.3 thousand million (UK)/billion (US) young and adult cattle. Under the assumption of an average daily intake of $40 \mathrm{~kg}$ pasture grass ( $7 \mathrm{~kg} \mathrm{DM}$ ) per head, an average cow) would consume 2.5 tons DM per year and the entire cattle population 3.25 thousand million (UK)/billion (US) tons, leading to an annual $\mathrm{CO}_{2}$ emission of approximately 1.8 thousand million (UK)/billion (US) tons, i.e. $6 \%$ of the total emission.

Furthermore, in pigs, the trend has been confirmed that an increase of $200 \mathrm{~g}$ in daily gain is followed by a decrease in $\mathrm{CO}_{2}$ release of $10-15 \%$. Breeding sows daily emit 1.5-1.7 $\mathrm{kg}$ of $\mathrm{CO}_{2}$ and fattening pigs about $1 \mathrm{~kg}$, i.e. the same as human with adequate nutrition.

The $\mathrm{CO}_{2}$ emissions of cattle and pigs cannot be considered as an additional factor destroying the climate. As mentioned above, nutrients are formed from the trace gas $\mathrm{CO}_{2}$ in the atmosphere and water by means of photosynthesis in the chlorophyll of plants. These nutrients, for instance those which are contained in grass and which are thus unusable directly by humans, are converted by the cattle into milk and meat. This conversion produces $\mathrm{CO}_{2}$, which is released into the atmosphere from whence it was originally taken up.Therefore, the $\mathrm{CO}_{2}$ produced during the metabolism of such plant nutrients is »emission neutral « and, in this case, does not emanate from cattle or pigs.

Furthermore, the presented results clearly show that, with increasing production levels, the $\mathrm{CO}_{2}$ emissions per unit product can be drastically reduced, as has been established for methane production (JENTSCH et al. 2007, PIATKOWSKI 2008). 


\section{References}

Beyer M, Jentsch W, Hoffmann L, Schiemann R (1994) Investigations on energy and nitrogen metabolism in pregnant and lactating sows as well in suckling piglets. 5. Energy and nitrogen metabolism of pregnant sows. Arch Anim Nutr 46, 173-205 [in German]

Beyer M, Jentsch W, Hoffmann L, Schiemann R (1995) Investigations on energy and nitrogen metabolism in pregnant and lactating sows as well in suckling piglets. 6. Comparison of measurements of energy and nitrogen metabolism in pregnant and non-pregnant sows. Arch Anim Nutr 47, 187-217 [in German]

Blischke S (1978) Analysis of energy and protein expenditure during rearing of young bulls in connection with the introduction of the GDR feed evaluation system in the VEG (Z) animal breeding. Diss. A, Akad. Landwirtschaftswiss. Berlin, Bereichskommission Tierprod. [in German]

Brouwer E (1965) Report of subcommittee on constants and faktors. In: Blaxter KL (ed) Energy Metabolism. Proc. 3rd Symposium, Troon, EAAP-Publ. 11, 441-3

Es van A J H, Nijkamp HJ (1969) Energy, Carbon and Nitrogen Balance Experiments with Lactating Cows. In: Blaxter KL, Kielanowski J, Thorbek G (eds) Energy Metabolism of Farm Animals. Proc. 4th Symposium, Warsaw, EAAP-Publ. 12, 209-12

Flachowsky G (2008) How we get $\mathrm{CO}_{2}$-Footprints for foods from animal origin? Arch Tierz $51 \mathrm{Sl}$, 67-82 [in German]

Flatt WP, Moe PW, Munson AW, Cooper T (1969) Energy Utilization by High Producing Dairy Cows. II. Summary of Energy Balance Experiments with Lactating Holstein Cows. In: Blaxter KL, Kielanowski J, Thorbek G (eds) Energy Metabolism of Farm Animals. Proc. 4th Symposium, Warsaw, EAAP-Publ. 12, 235-8

Franke M (1977) Investigation of energy and protein expenditure for dairy cows and sheep during the complex introduction of the GDR feed evaluation system in the VEG Schwanebeck. Diss. A. Akad. Landwirtschaftswiss. Berlin, Bereichskommission Tierprod. [in German]

Gutbier H (1984) Investigation and analysis of energy and protein expenditure during rearing of female cattle in the ZGE Falkenthal. Diss. A. Akad. Landwirtschaftswiss. Berlin, Bereichskommission Tierprod. [in German]

Hoffmann L, Beyer M, Schiemann R, Jentsch W (1990) Energy requirement of pregnant and lactating sows. Arch Anim Nutr 40, 279-96 [in German]

Hoffmann L, Jentsch W (1988) Studies of the energy requirement of young female cattle. 5. Energy intake and energy expenditure. Arch Anim Nutr 38, 163-73 [in German]

Hoffmann L, Jentsch W, Wittenburg H, Schiemann R (1972) Utilization of feed energy for milk production. 5 th comm. Comprehensive evaluation of experiments with dairy cattle on dependence of energy utilization on nutrient composition of rations in the Oskar-Kellner-Institut. Arch Tierernähr 22, 721-42 [in German]

Hoffmann L, Schiemann R (1980) From calorie to Joule. New proportions in measuring energy metabolism and calculating the parameters of energetic feed evaluation. Arch Tierernähr 30, 733-42 [in German]

Hoffmann L, Schiemann R, Jentsch W (1979) Utilization of feed energy by growing pigs. 3. Energy requirement for growth and fattening of pigs. Arch Tierernähr 29, 93-109 [in German]

Hoffmann L, Schiemann R, Jentsch W (1981) On the energy requirement of growing bulls. Arch Tierernähr 31, 481-96 [in German]

Hoffmann L, Schiemann R, Jentsch W (1983) Joint investigations for the more precise determination of energy and protein requirement of fattening pigs. 3. Energy requirement of hybrid pigs. Arch Tierernähr 33, 571-83 [in German]

Hoffmann L, Schiemann R, Jentsch W (1988) Studies of the energy requirement of young female cattle. 6. Energy requirement. Arch Anim Nutr 38, 299-315 [in German]

Hoffmann L, Schiemann R, Jentsch W, Henseler G (1974) Utilization of feed energy for milk production. 10. Energy standards for dairy cows. Arch Tierernähr 24, 245-61 [in German]

Honing van der Y, Steg A (1980) Calculation of energy value of feedstuffs for milk production: Comparison of various feed evaluation systems. In: Mount LE (ed): Energy Metabolism. Proc. 8th Symposium, Cambridge, EAAP-Publ. 26, 23-6

Honing van der Y, Steg A (1990) Comparison of feed evaluation systems of feeds for ruminants. In: Wiseman J, Col DJA (eds) Feedstuff Evaluation. Butterworth, London

IPCC Report, in: Climate Change 2007 - The Physical Science Basis Contribution of Working Group I to the 4th Assessment Report of the IPCC, Cambridge University Press

Jentsch W, Chudy A, Beyer M (2004) The Rostock feed evaluation system. Reference numbers of feed value and requirement on the base of net energy (revised monograph of a team of authors) 
Jentsch W, Derno M, Klein M, Junghans, P, Löhrke B (2000) Research Note: Is Starch Utilization for Fat Deposition in Man Different From that in Animals? Arch Anim Nutr 53, 395-8

Jentsch W, Derno M, Weiher O (2001) Heat release of dairy cows in dependence on performance - a study. Arch Tierz 44, 599-610 [in German]

Jentsch W, Hoffmann L (1977) Utilization of feed energy by growing pigs. 2. Energy and nitrogen metabolism in the fattening range between 30 and $125 \mathrm{~kg}$. Arch Tierernähr 27, 491-507 [in German]

Jentsch W, Schiemann R, Hoffmann L (1983) Joint investigations for the more precise determination of energy and protein requirement of fattening pigs. 2. Energy and nitrogen metabolism of fattening hybrids in the fattening range between 30 and $120 \mathrm{~kg}$. Arch Tierernähr 33, 552-70 [in German]

Jentsch W, Schweigel M, Weissbach F, Scholze H, Pittroff W, Derno M (2007) Methane production in cattle calculated by the nutrient composition of the diet. Arch Anim Nutr 61, 10-9

Jentsch W, Wittenburg H, Schiemann R (1977) Investigations on the energetic feed value of cereal complete plants pellets. Arch Tierernähr 27, 99-116 [in German]

Jentsch W, Wittenburg H, Schiemann R (1978) Investigations on digestibility and utilization of rations with different treated straw. 3 . Investigations on digestibility and utilization of rations with different treated straw by fattening bulls. Arch Tierernähr 28, 407-16 [in German]

Junghans $\mathrm{P}$, Jentsch W, Derno M (2008) Non-invasive $13 \mathrm{C}$ bicarbonate tracer technique for measuring energy expenditure in men - A pilot study. e-SPEN (Europ e-J Clinic Nutr Metabol 3, e46-e51

Piatkowski B, Gürtler H, Voigt J (1990) Basics of ruminant nutrition. Gustav Fischer Verlag, Jena, Germany [in German]

Piatkowski B (2008) The cow as a »climate killer«? Neue Landw 2, 59 [in German]

Schiemann R, Henseler G, Jentsch W, Wittenburg H (1974) Utilization of feed energy for milk production. 8. Measurements of energy metabolism on high yielding cows in early stage of lactation. Arch Tierernähr 24, 105-37 [in German]

Schiemann R, Hoffmann L, Neubert M (1982): Comparison of performance of different energetic feed evaluation systems for determination of energy requirements for milk production. Tierzucht $36,70-2$ [in German]

Schiemann R, Jentsch W, Hoffmann L (1987) Investigations on energy requirement of female young cattle. 2. Nutrient and energy metabolism. Arch Anim Nutr 37, 971-93 [in German]

Schiemann R, Jentsch W, Hoffmann L, Wittenburg H (1970) Utilization of feed energy for milk production. 1. Investigations on animals with different performance. Arch Tierernähr 20, 227-51 [in German]

Schiemann R, Jentsch W, Wittenburg H, Hoffmann L (1976) Utilization of feed energy by growing bulls. 1. Experimental design and results of energy and nutrient metabolism. Arch Tierernähr 26, 491-517 [in German]

Wittenburg H, Jentsch W, Hoffmann L, Schiemann R (1976) Investigations on formic acid additives to rations on energy metabolism of sheep and young bulls. Arch Tierernähr 26, 839-48 [in German]

Received 24 February 2009, accepted 25 July 2009.

Corresponding author:

Dr. rer. nat. MICHAEL DERNO

email: derno@fbn-dummerstorf.de

Forschungsbereich Ernährungsphysiologie `Oskar Kellner«, Forschungsinstitut für die Biologie landwirtschaftlicher Nutztiere, Wilhelm-Stahl-Allee 2, 18196 Dummerstorf, Germany 